\title{
BMJ Open Effect of medical student debt on mental health, academic performance and specialty choice: a systematic review
}

\author{
Monique Simone Pisaniello, ${ }^{1}$ Adon Toru Asahina, ${ }^{1}$ Stephen Bacchi, ${ }^{2}$ \\ Morganne Wagner, ${ }^{3}$ Seth W Perry, ${ }^{4}$ Ma-Li Wong, ${ }^{4}$ Julio Licinio ${ }^{4}$
}

To cite: Pisaniello MS, Asahina AT, Bacchi S, et al. Effect of medical student debt on mental health, academic performance and specialty choice: a systematic review. BMJ Open 2019;9:e029980. doi:10.1136/ bmjopen-2019-029980

- Prepublication history and additional material for this paper are available online. To view these files, please visit the journal online (http://dx.doi. org/10.1136/bmjopen-2019029980).

Received 22 February 2019 Revised 30 April 2019 Accepted 30 May 2019

Check for updates

(c) Author(s) (or their employer(s)) 2019. Re-use permitted under CC BY-NC. No commercial re-use. See rights and permissions. Published by BMJ.

${ }^{1}$ School of Medicine, The University of Adelaide, Adelaide, South Australia, Australia ${ }^{2}$ Royal Adelaide Hospital, Adelaide, South Australia, Australia

${ }^{3}$ State University of New York Upstate Medical University, Syracuse, New York, USA ${ }^{4}$ Department of Psychiatry, State University of New York Upstate Medical University, Syracuse, New York, USA

Correspondence to Miss Monique Simone Pisaniello; monique.pisaniello@student. adelaide.edu.au

\section{ABSTRACT}

Objectives With the high and rising total cost of medical school, medical student debt is an increasing concern for medical students and graduates, with significant potential to impact the well-being of physicians and their patients. We hypothesised that medical student debt levels would be negatively correlated with mental health and academic performance, and would influence career direction (ie, medical specialty choice).

Design We performed a systematic literature review to identify articles that assessed associations between medical student mental health, academic performance, specialty choice and debt. The databases PubMed, Medline, Embase, Scopus and PsycINF0 were searched on 12 April 2017, for combinations of the medical subject headings Medical Student and Debt as search terms. Updates were incorporated on 24 April 2019.

Results 678 articles were identified, of which 52 met the inclusion criteria after being reviewed in full text. The majority of studies were conducted in the USA with some from Canada, New Zealand, Scotland and Australia The most heavily researched aspect was the association between medical student debt and specialty choice, with the majority of studies finding that medical student debt was associated with pursuit of higher paying specialties. In addition, reported levels of financial stress were high among medical students, and correlated with debt. Finally, debt was also shown to be associated with poorer academic performance.

Conclusions Medical student debt levels are negatively associated with mental well-being and academic outcomes, and high debt is likely to drive students towards choosing higher paying specialties. Additional prospective studies may be warranted, to better understand how educational debt loads are affecting the well-being, career preparation and career choices of physicians-in-training, which may in turn impact the quality of care provided to their current and future patients.

\section{INTRODUCTION}

As medical students' debt burdens rise along with the cost of education, the potential for this debt to significantly impact their wellbeing, career preparation and career choices, and thus the quality of care that they can provide to their current and future patients, also grows. This debt has long been a concern

\section{Strengths and limitations of this study}

- A unique systematic review that evaluates and integrates the strength of the evidence for the effects of medical education debt on medical students' and future physicians' mental health, academic performance and area of specialisation.

- Fifty-two articles were included in the initial systematic review, with seven added on 24 April 2019

- This review does not assess evidence from primary literature that was not available in English.

- Articles from only six countries met criteria for the systematic review.

for current and prospective medical students, as well as graduates. Education-related costs incurred by medical students may include, at minimum, housing and living expenses, health insurance and tuition fees, and most medical students incur significant debt to cover these costs, usually in the form of government or private loans. In the USA, median indebtedness at graduation was US\$192000 in 2017 compared with US\$50000 in $1992,{ }^{12}$ which is an approximately $220 \%$ increase even after accounting for the rate of inflation. Increases in these costs have outpaced the relative compensation of primary care physicians and specialists, as well as grants and scholarships. ${ }^{3}$ The effects of this debt are significant and myriad; it can negatively impact mental health and academic performance, and influence specialty choice. ${ }^{45}$ This issue is of great importance with the recent focus on mental health concerns in medical students and physicians. ${ }^{6}$

\section{BACKGROUND}

Medical student debt is commonly accrued as a result of borrowing to cover the costs of medical school tuition fees, housing and living expenses. For many, this debt may be additive with pre-existing educational debt, 
the levels of which are already considered to constitute a 'student debt crisis' in many parts of the world, particularly the USA. Australia has Commonwealth supported places, that is, subsidised university education, available to all Australian citizen university students through the Higher Education Contribution Scheme-Higher Education Loan Programme, which does not incur interest and is repaid once an income threshold is reached (US\$51 957 for the 2018-2019 financial year). ${ }^{8}$ New Zealand has a similar loan system to Australia, with Government Student Loan schemes available to all students. America offers three main types of loans: (1) federal loans, available to all students studying at least half-time, the accumulating interest on which may be subsidised (ie, paid) or unsubsidised (not paid) by the government during the student's time in school, (2) Stafford or Perkins loans that accrue interest but do not require repayment until 6 months after graduation and (3) private (unsubsidised) loans from third parties like banks or state loans, sometimes offered directly from the student's college or state. ${ }^{9}$ Canada offers grants and student loans to those with financial need studying at least part-time, which vary by province and with stated lifetime limits up to 400 weeks (or 520 weeks for those with a permanent disability). ${ }^{10}$ Typically, these loans do not incur interest until the lifetime limit is reached, and repayments are not commenced until 6 months after the student leaves or completes his/ her studies. ${ }^{10}$

There is contrasting evidence regarding the extent to which debt influences choice of medical specialty. ${ }^{11}$ Results have varied between studies, with high and low debt being associated with desire for both high paying specialties and practice in primary care. The income gap between primary care and subspecialist physicians has risen to nearly threefold in some countries. ${ }^{12}$ This wage gap may contribute to the role debt plays in specialty choice. It is important to elucidate the extent to which debt affects these choices, particularly in regard to high levels of physician burnout associated with unsatisfying career choices, and insufficient numbers of primary care doctors in many countries.

Despite these concerning statistics, few studies have explored how medical students' debt affects their mental health and academic performance. It is important to investigate the links between debt and these outcomes in order to inform interventions aimed at alleviating student stressors, and to guide specialty planning. This review was conducted to appraise the available evidence regarding the extent to which medical student debt impacts mental health, academic performance and specialty choice.

\section{METHODS}

\section{Search strategy}

We searched the databases PubMed, Medline, Embase, Scopus and PsycINFO on 12 April 2017 for combinations of the medical subject headings Medical Student and Debt as search terms. A full string of search terms for PubMed is provided in the online supplementary figure S1. A language filter was then applied to exclude articles not published in English. The databases were searched from inception: PubMed 1996, Medline 1946, Embase 1974, Scopus 2004, and PsycINFO 1967. Updates were incorporated on 24 April 2019.

\section{Eligibility criteria}

After the application of this filter, articles were included if they fulfilled the following criteria: (1) a primary clinical research paper; (2) specifically assessed medical students (ie, not mixed with other student groups); (3) reported on the effect of debt on (a) medical student mental health, (b) academic performance or (c) specialty choice and finally (4) available in full text.

\section{Selection of studies}

The titles and abstracts of the included publications were examined by one author (MSP), and consensus achieved in cases of uncertainty through discussion with a second author (SB), to determine if they met inclusion criteria. Those publications that were likely to meet the eligibility criteria were reviewed in full text before being included or excluded by one author (MSP). To further reduce any possible selection bias, the suggested included studies were then reviewed again by a second author (ATA) with respect to eligibility. Those for which likely eligibility could not be determined from the title and abstract were also retrieved in full text and analysed for inclusion or exclusion. Interlibrary requests were sent for any full texts that could not be accessed through the online databases. Reference lists of the included articles were searched for other studies that might be eligible.

\section{Data extraction and quality assessment}

Extraction of the following data and quality assessment for each of the included articles was completed using a standardised form in Microsoft Excel (Microsoft, Redmond, Washington, USA): study characteristics (description of study protocol, how results were assessed); characteristics of the study population (sample size, stage of medical training, undergraduate or postgraduate degree, country of study); information to evaluate risk of bias (anonymity of surveys, selection bias, presence of control group, selective reporting bias, quality assessment as seen below) and finally outcomes relevant to one of the three areas of interest (mental health, academic performance or specialty choice).

\section{Quality of evidence}

The quality of evidence of the included articles was assessed using the Oxford 2011 level of evidence, 'quality rating scheme for studies and other evidence', a commonly accepted tool for rating evidence. It rates trials from 1 to 5 as follows: systematic review with meta-analysis, prospective comparative cohort trial, retrospective cohort study, cross-section study and case reports. ${ }^{13} 14$ The articles' level of evidence assessment and significant data points are summarised in tables 1-3. 
Table 1 Articles investigating the effect on Mental Health

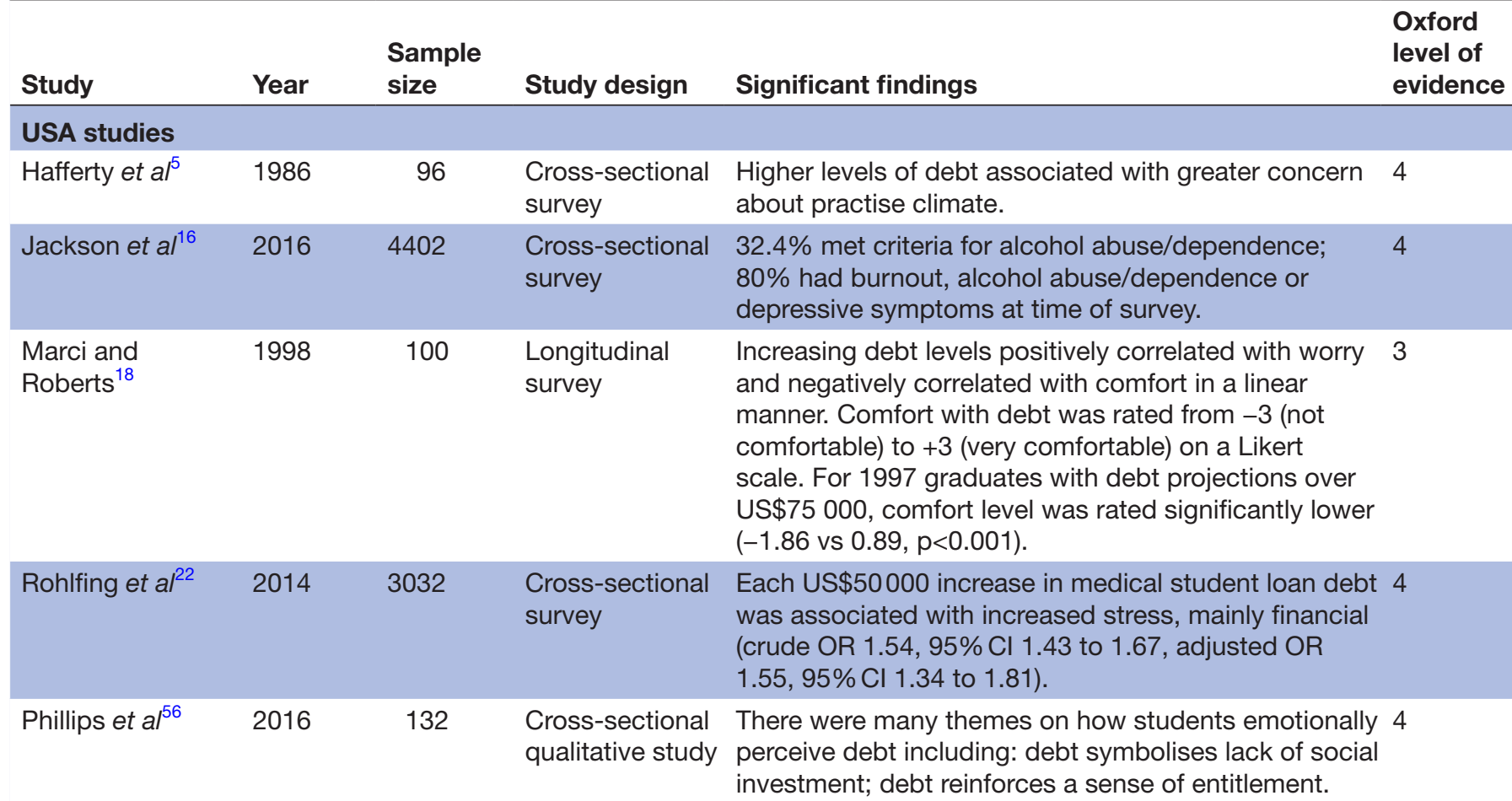

$\begin{array}{llll}\text { Canadian studies } & & \\ \text { Kwong et al }{ }^{17} & 2005 & 2994 & \begin{array}{l}\text { Cross-sectional } \\ \text { survey }\end{array}\end{array}$

$\begin{array}{llll}\text { Merani et } a l^{19} & 2010 & 7795 & \begin{array}{l}\text { Longitudinal } \\ \text { survey }\end{array} \\ \text { Morra et } a l^{20} & 2008 & 549 & \begin{array}{l}\text { Cross-sectional } \\ \text { survey }\end{array}\end{array}$

Compared with non-rural, rural students reported more debt at both entry to medical school and on graduation. They were also more likely to report fairto-extreme levels of financial stress compared with non-rural $(61.7 \%$ vs $55.4 \%, \mathrm{p}=0.03)$.

More students in 2007 than 2001 expected to graduate with debt $(89.7 \%$ vs $75.7 \%)$. Rose from US\$14500 to US\$30000 in Quebec but US\$50 000 to US\$90 000 outside Quebec $(p<0.0001)$. Quebec students anticipated less debt and less likely to report financial stress than those outside Quebec.

Perceived financial stress correlated significantly with both current debt $(r=0.303)$ and anticipated debt $(r=0.455)$. The anticipated debt was also able to account for an additional $11.5 \%$ of the variance in reported stress over that predicted by current debt alone.

$\begin{array}{llcl}\text { Kwong et } a l^{25} & 2002 & 2994 & \begin{array}{l}\text { Cross-sectional } \\ \text { survey }\end{array} \\ \text { McLuckie et al }{ }^{27} & 2017 & 381 & \begin{array}{l}\text { Cross-sectional } \\ \text { survey }\end{array}\end{array}$

Students reported that their financial situation was 'very' or 'extremely' stressful (21.4\% vs $26 \%)$, opposite result was found in control groups.

Feeling psychologically/emotionally unsupported at their university, which increased through the years of medical training, was a predictor of psychological distress and burnout. This risk was reduced in those who felt supported.

$\begin{array}{llll}\text { New Zealand studies } & & \\ \text { Gill et } a l^{15} & 2001 & 179 & \begin{array}{l}\text { Cross-sectional } \\ \text { survey }\end{array}\end{array}$

\section{who felt supported.}

Worrying about debt increased in sixth year students with levels of debt: those who never worried (14\%) had debts of US\$2500, those who always worried $(7 \%)$ had debts of US $\$ 86750$. Frequency of worrying for all students was never $(20 \%)$, rarely $(10 \%)$, sometimes $(34 \%)$, often $(30 \%)$, always $(5 \%)$. 
Table 1 Continued

\begin{tabular}{llclll}
\hline Study & Year & $\begin{array}{l}\text { Sample } \\
\text { size }\end{array}$ & Study design & Significant findings & $\begin{array}{l}\text { Oxford } \\
\text { level of } \\
\text { evidence }\end{array}$ \\
\hline $\begin{array}{l}\text { Perry and } \\
\text { Wilkinson }^{26}\end{array}$ & 2010 & 372 & $\begin{array}{l}\text { Cross-sectional } \\
\text { survey }\end{array}$ & $\begin{array}{l}32 \% \text { of students always or often worry about debt, } \\
34 \% \text { sometimes. The amount of worry was positively } \\
\text { correlated with amount of debt. }\end{array}$
\end{tabular}

\section{Scottish study}

\begin{tabular}{|c|c|c|c|c|}
\hline Ross et $a l^{23}$ & 2006 & 352 & $\begin{array}{l}\text { Cross-sectional } \\
\text { survey }\end{array}$ & $\begin{array}{l}42 \% \text { reported stress about money contributed to up } \\
\text { to one-fourth of their stress, nearly } 16 \% \text { stated stress } \\
\text { about money made up }>50 \% \text { of their overall stress; } \\
37.4 \% \text { thought worrying about money affected their } \\
\text { studies. Money came in as the second most common } \\
\text { cause of stress after coursework at } 78.1 \% \text {. }\end{array}$ \\
\hline
\end{tabular}

\section{Australian study}

\begin{tabular}{|c|c|c|c|c|}
\hline Rogers et $a l^{24}$ & 2012 & 755 & $\begin{array}{l}\text { Cross-sectional } \\
\text { survey }\end{array}$ & $\begin{array}{l}\text { Barriers (including medical specialty choice, family and } 4 \\
\text { lifestyle conditions, male domination, hours of work), } \\
\text { concern about debt, academic stress accounted for } \\
12.7 \% \text { of variance on well-being. }\end{array}$ \\
\hline
\end{tabular}

\section{Role of funding source}

The University of Adelaide provided institutional funds for retrieval of interlibrary requests.

\section{Patient and public involvement}

Patients and the public were not involved in this systematic review.

\section{RESULTS}

On the initial database searches, 678 potential articles were identified. Six hundred and sixty-seven of these were in English, and after reviewing these titles and abstracts, two hundred and twenty were reviewed in full text. Fifty-two articles met the inclusion criteria and were included in this review (figure 1). A further seven articles were added in the 24th of April 2019 review.

The majority of the identified (included) studies examined the influence of debt on specialty choice. Only 14 articles assessed the influence of debt on (a) medical student mental health. ${ }^{5}{ }^{15-27}$ Four studies assessed debt in relation to (b) academic performance. ${ }^{152328} 29$ Fifty articles assessed the relationship between debt and (C) specialty choice. ${ }^{4511} 1217182122252630-69$ Several articles fell under one or more of these categories. All but one $\mathrm{e}^{27}$ of the additional articles from the 2019 review examined the effect on (c) specialty choice. ${ }^{64-69}$

Table 2 Articles investigating the effect on academic performance

\begin{tabular}{|c|c|c|c|c|c|}
\hline Study & Year & $\begin{array}{l}\text { Sample } \\
\text { size }\end{array}$ & Study design & Significant findings & $\begin{array}{l}\text { Oxford } \\
\text { level of } \\
\text { evidence }\end{array}$ \\
\hline Gill et $a l^{15}$ & 2001 & 179 & $\begin{array}{l}\text { Cross- } \\
\text { sectional } \\
\text { survey }\end{array}$ & $\begin{array}{l}\text { Impact of debt: } 46 \% \text { said debt never impacted full participation } \\
\text { in course, impaired rarely for } 31 \% \text {, sometimes for } 21 \% \text { and often } \\
\text { for } 2 \% \text {. }\end{array}$ & 4 \\
\hline Ross et $a l^{23}$ & 2006 & 352 & $\begin{array}{l}\text { Cross- } \\
\text { sectional } \\
\text { survey }\end{array}$ & $\begin{array}{l}\text { No significant relationship between total debt and performance } \\
\text { (as measured using class rank). Students who reported worrying } \\
\text { about money affected their performance generally had lower } \\
\text { ranks and higher outstanding debt, those who already had } \\
\text { a degree were more likely to say that money affects their } \\
\text { performance. }\end{array}$ & 4 \\
\hline
\end{tabular}

\begin{tabular}{|c|c|c|c|c|}
\hline $\begin{array}{l}\text { Andriole } \\
\text { and Jeffe }{ }^{28}\end{array}$ & 2010 & 86114 & $\begin{array}{l}\text { Retrospective } \\
\text { longitudinal } \\
\text { study }\end{array}$ & $\begin{array}{l}\text { There was a progressive decrease in the per cent of students } \\
\text { graduating with optimal/passing scores with increasing debt } \\
\text { levels: no debt-90.1\%; 100\%-9999\%-86.8\%; } 10000 \%- \\
24999 \%-87 \% ; 25000-49999 \%-83.6 \% ;>50000 \%-76.4 \% \text {. }\end{array}$ \\
\hline
\end{tabular}


Table 3 Articles investigating the effect on specialty choice

\begin{tabular}{|c|c|c|c|c|c|}
\hline Study & Year & $\begin{array}{l}\text { Sample } \\
\text { size }\end{array}$ & Study design & Significant Findings & $\begin{array}{l}\text { Oxford } \\
\text { level of } \\
\text { evidence }\end{array}$ \\
\hline \multicolumn{6}{|c|}{ USA studies associating debt with high paying specialties } \\
\hline $\begin{array}{l}\text { Hafferty and } \\
\text { Boulger }\end{array}$ & 1986 & 96 & $\begin{array}{l}\text { Cross-sectional } \\
\text { survey }\end{array}$ & $\begin{array}{l}\text { Higher debt led to specialist medical fields over } \\
\text { generalist. }\end{array}$ & 4 \\
\hline Colquitt et al $^{11}$ & 1996 & N/A & $\begin{array}{l}\text { Cross-sectional } \\
\text { (American Medical } \\
\text { Colleges' (AAMC) } \\
\text { Medical Student } \\
\text { Graduation } \\
\text { Questionnaire (GQ) } \\
\text { and Matriculating } \\
\text { Student } \\
\text { Questionnaire } \\
\text { (MSQ))) }\end{array}$ & High debt led to high paying specialties. & 4 \\
\hline Andriole et $a l^{30}$ & 2008 & 1833 & $\begin{array}{l}\text { Cross-sectional } \\
\text { survey (AAMC) }\end{array}$ & Lower debt led to high paying specialties. & 4 \\
\hline $\begin{array}{l}\text { Azizzadeh et } \\
a l^{31}\end{array}$ & 2003 & 111 & $\begin{array}{l}\text { Cross-sectional } \\
\text { survey }\end{array}$ & $\begin{array}{l}\text { Lower concern about debt led to high paying } \\
\text { specialties. }\end{array}$ & 4 \\
\hline Bazzoli ${ }^{32}$ & 1985 & 3855 & $\begin{array}{l}\text { Cross-sectional } \\
\text { survey }\end{array}$ & $\begin{array}{l}\text { Higher subsidised debt led to primary care (PC) } \\
\text { specialties (US } \$ 10000 \text { increase in debt increases PC } \\
\text { by } 5.3 \% \text { ). } \\
\text { Higher HEAL debt led to high paying specialties } \\
\text { (US } \$ 10000 \text { increase decreased PC by } 7.5 \%) \text {. }\end{array}$ & 4 \\
\hline $\begin{array}{l}\text { Andriole and } \\
\text { Jeffe }^{28}\end{array}$ & 2010 & N/A & $\begin{array}{l}\text { Longitudinal survey } \\
\text { (AAMC) }\end{array}$ & $\begin{array}{l}\text { Higher debt led to less generalist/primary care } \\
\text { specialty choices, but not associated with family } \\
\text { medicine specialty choices. }\end{array}$ & 3 \\
\hline $\begin{array}{l}\text { Kassebaum } \\
\text { and Szenas }\end{array}$ & 1993 & 12131 & $\begin{array}{l}\text { Cross-sectional } \\
\text { survey (AAMC) }\end{array}$ & $\begin{array}{l}\text { Debt had a greater influence in those choosing } \\
\text { surgical and support specialties compared with } \\
\text { generalist and medical specialties. There was also a } \\
\text { higher number of students citing an influence in the } \\
1993 \text { graduate class compared with the } 1992 \text { class. } \\
\text { However, interest in generalist specialties increased } \\
\text { during this time compared with the other specialties. }\end{array}$ & 4 \\
\hline $\begin{array}{l}\text { Kassebaum } \\
\text { and Szenas }\end{array}$ & 1994 & 8128 & $\begin{array}{l}\text { Cross-sectional } \\
\text { survey (AAMC) }\end{array}$ & $\begin{array}{l}\text { Limited influence but slightly higher for surgical }(0.93) \\
\text { compared with generalist }(0.54) \text {. }\end{array}$ & 4 \\
\hline $\begin{array}{l}\text { Kassebaum } \\
\text { and Szenas }\end{array}$ & 1993 & 12096 & $\begin{array}{l}\text { Cross-sectional } \\
\text { survey (AAMC) }\end{array}$ & $\begin{array}{l}\text { Under-represented minority students were more } \\
\text { likely to have debt than white and other non-under- } \\
\text { represented minorities (majority students). Minority } \\
\text { cited debt as a strong or major influence more } \\
\text { frequently, particularly in those wanting to pursue } \\
\text { medical/surgical/support specialties compared with } \\
\text { generalist certifications. }\end{array}$ & 4 \\
\hline
\end{tabular}


Table 3 Continued

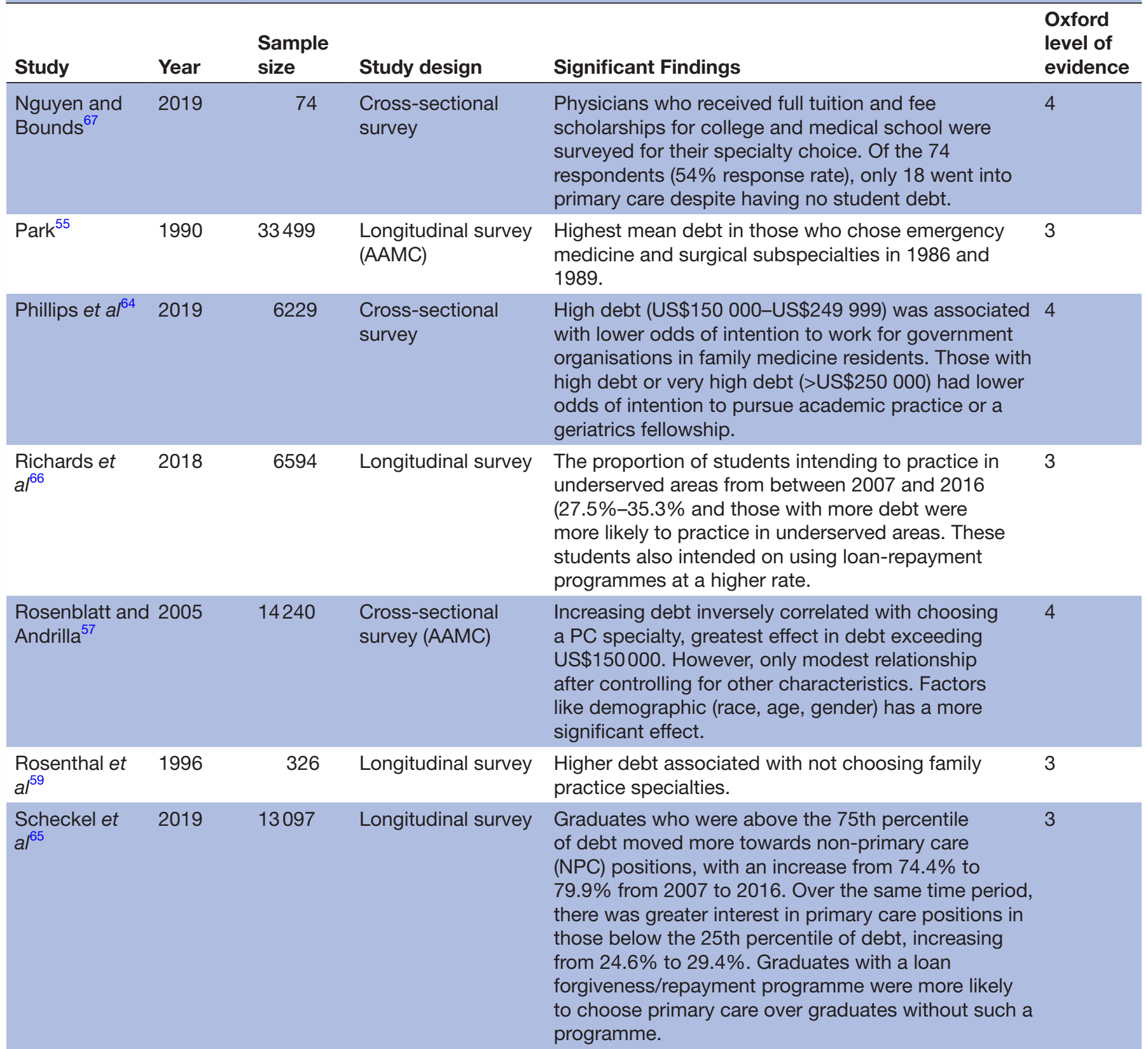

\section{USA studies associating debt with low paying specialties}

$\begin{array}{lll}\text { Phillips et } a l^{21} 2010 \quad 983 & \begin{array}{l}\text { Cross-sectional } \\ \text { survey }\end{array} & \begin{array}{l}\text { Those with any level of debt were two-times as likely } \\ \text { to choose PC compared with no debt, but those } \\ \text { with no debt were less likely to be under-represented } \\ \text { minorities and their families had higher incomes. Also, } \\ \text { those from middle-income families were less likely to } \\ \text { choose primary care as their debt levels increased. }\end{array} \\ \end{array}$

Rohlfing et al ${ }^{22} 2014 \quad 3032 \quad \begin{aligned} & \text { Cross-sectional } \\ & \text { survey }\end{aligned}$

Each decrease in relative debt decreased salary of 4 desired specialty by US $\$ 21000$, there was not a statistically significant relationship with an increase in relative debt.

An increase in premedical student loan debt by US $\$ 20000$ increased chance of choosing a PC specialty. Contrarily, a decrease in relative debt as measured by an increased proportion of estimated cost of attendance saved was also associated with choosing PC. 
Table 3 Continued

\begin{tabular}{|c|c|c|c|c|c|}
\hline Study & Year & $\begin{array}{l}\text { Sample } \\
\text { size }\end{array}$ & Study design & Significant Findings & $\begin{array}{l}\text { Oxford } \\
\text { level of } \\
\text { evidence }\end{array}$ \\
\hline Bazzoli $^{32}$ & 1985 & 3855 & $\begin{array}{l}\text { Cross-sectional } \\
\text { survey }\end{array}$ & $\begin{array}{l}\text { Higher subsidised debt led to primary care specialties } \\
\text { (US } \$ 10000 \text { increase in debt increases PC by } 5.3 \%) \text {. } \\
\text { Higher HEAL debt led to high paying specialties } \\
\text { (US } \$ 10000 \text { increase decreased PC by } 7.5 \% \text { ). }\end{array}$ & 4 \\
\hline $\begin{array}{l}\text { Henderson et } \\
a l^{40}\end{array}$ & 1996 & 144 & $\begin{array}{l}\text { Longitudinal survey } \\
\text { (preclerkship and } \\
\text { postclerkship } \\
\text { survey) }\end{array}$ & High debt led to primary care specialties. & 3 \\
\hline Jeffe et $a l^{42}$ & 2008 & 87763 & $\begin{array}{l}\text { Retrospective } \\
\text { longitudinal (AAMC) }\end{array}$ & $\begin{array}{l}\text { Lower debt led to more likely to stay with academic } \\
\text { medicine if considered initially. But does not increase } \\
\text { chance of changing to academic medicine if did not } \\
\text { initially consider it. }\end{array}$ & 3 \\
\hline $\begin{array}{l}\text { McLaughlin et } \\
a l^{63}\end{array}$ & 1991 & 983 & Longitudinal survey & $\begin{array}{l}\text { Mean debt rising correlated with effect on 'choice of } \\
\text { specialty', but weak relationship. Ratings of effect of } \\
\text { debt greater in lower pay specialties compared with } \\
\text { higher paying. }\end{array}$ & 3 \\
\hline
\end{tabular}

\section{USA studies which found no or minimal association between debt and specialty choice}

\begin{tabular}{|c|c|c|c|c|c|}
\hline $\begin{array}{l}\text { Diamond et } \\
\mathrm{al}^{34}\end{array}$ & 1994 & 104 & $\begin{array}{l}\text { Cross-sectional } \\
\text { survey (conjoint } \\
\text { analysis) }\end{array}$ & $\begin{array}{l}\text { Out of } 6 \text { factors asked for influencing specialty } \\
\text { choice, loan repayment contributed } 5 \% \text { and debt } 4 \% \\
\text { of variance in specialty choice. The other factors were } \\
\text { more influential. }\end{array}$ & 4 \\
\hline Kahn et al ${ }^{43}$ & 2006 & 2022 & $\begin{array}{l}\text { Retrospective } \\
\text { longitudinal study }\end{array}$ & No significant influence. & 3 \\
\hline Kassler et $a l^{48}$ & 1991 & 293 & $\begin{array}{l}\text { Cross-sectional } \\
\text { survey (eight } \\
\text { medical schools) }\end{array}$ & No significant influence. & 4 \\
\hline Mutha et $a l^{52}$ & 1997 & 52 & $\begin{array}{l}\text { Cross-sectional } \\
\text { study (group } \\
\text { discussion) }\end{array}$ & No significant influence. & 4 \\
\hline & 2016 & 29227 & $\begin{array}{l}\text { Cross-sectional } \\
\text { study (AAMC 11-13) }\end{array}$ & $\begin{array}{l}\text { Educational debt was ranked as the least influential } \\
\text { factor in choosing a specialty out of the factors listed. }\end{array}$ & 4 \\
\hline
\end{tabular}

Continued 
Table 3 Continued

\begin{tabular}{|c|c|c|c|c|c|}
\hline Study & Year & $\begin{array}{l}\text { Sample } \\
\text { size }\end{array}$ & Study design & Significant Findings & $\begin{array}{l}\text { Oxford } \\
\text { level of } \\
\text { evidence }\end{array}$ \\
\hline $\begin{array}{l}\text { Rosenthal et } \\
\left.a\right|^{58}\end{array}$ & 1994 & 688 & $\begin{array}{l}\text { Cross-sectional } \\
\text { study }\end{array}$ & $\begin{array}{l}\text { Little difference in mean debt between those selecting } \\
\text { PC and NPC. However, } 10 \% \text { of NPC students said } \\
\text { they would change to PC if medical school loans were } \\
\text { repaid. }\end{array}$ & 4 \\
\hline
\end{tabular}

\section{USA studies finding an association between debt and specialty choice but did not specify direction}

\begin{tabular}{|c|c|c|c|c|c|}
\hline $\begin{array}{l}\text { Marci and } \\
\text { Roberts }^{18}\end{array}$ & 1998 & 400 & Longitudinal survey & $\begin{array}{l}\text { At debt }<\text { US } \$ 75000 \text { and influence on specialty choice } \\
\text { not correlated. } \\
\text { At debt US } \$ 25000-U S \$ 75000 \text { increasing debt } \\
\text { correlated with increasing influence. } \\
\text { At debt }>\text { US } \$ 75000 \text { had more influence on specialty } \\
\text { choice. }\end{array}$ & 3 \\
\hline Mader et $a l^{49}$ & 2014 & 500 & Longitudinal survey & $\begin{array}{l}\text { Influence on specialty choice for "amount of } \\
\text { educational debt I have" rose in importance from the } \\
\text { beginning of first year to third year, while interest in } \\
\text { content declined. }\end{array}$ & 3 \\
\hline Phillips et $\left.a\right|^{56}$ & 2016 & 132 & $\begin{array}{l}\text { Cross-sectional } \\
\text { qualitative (essays) }\end{array}$ & $48 \%$ said debt limited career choice preferences. & 4 \\
\hline $\begin{array}{l}\text { Teitelbaum et } \\
a^{60}\end{array}$ & 2009 & 2345 & $\begin{array}{l}\text { Cross-sectional } \\
\text { survey ( } 21 \text { colleges } \\
\text { of osteopathic } \\
\text { medicine and } 2 \\
\text { branch campuses) }\end{array}$ & $\begin{array}{l}\text { As average debt increased, students were more likely } \\
\text { to say it had an impact on specialty choice. However, } \\
62.8 \% \text { said debt had no impact. }\end{array}$ & 4 \\
\hline
\end{tabular}

\section{Studies outside the USA finding an association between debt and specialty choice}

\section{Canada}

$\begin{array}{lll}\text { Kwong et al }^{17} 2005 \quad 2994 & \begin{array}{l}\text { Cross-sectional } \\ \text { survey }\end{array}\end{array}$

More urban students reported that financial

considerations around debt would be a major influence on specialty choice.

However, more rural students than urban students enter with debt and among those with debt have greater debt at both entry and completion of medical school.

\begin{tabular}{|c|c|c|c|c|c|}
\hline Kwong et $\left.a\right|^{25}$ & 2002 & 2994 & Longitudinal survey & $\begin{array}{l}\text { Students reported debt being a major influence } \\
\text { on choice of specialty and was higher in first- year } \\
\text { students compared with fourth-year students. } \\
\text { More students in } 2000 \text { ( } 28.5 \%) \text { compared with } 1997 \\
(21.2 \%) \text { stated financial considerations would be a } \\
\text { major influence on chosen practice location. }\end{array}$ & 3 \\
\hline Gill et $a l^{36}$ & 2012 & 280 & $\begin{array}{l}\text { Cross-sectional } \\
\text { survey }\end{array}$ & $\begin{array}{l}\text { Medical students with urban background: specialty } \\
\text { choice influenced by current debt load. }\end{array}$ & 4 \\
\hline
\end{tabular}


Table 3 Continued

\begin{tabular}{lllll}
\hline Study & Year & $\begin{array}{l}\text { Sample } \\
\text { size }\end{array}$ & Study design & Significant Findings \\
\hline New Zealand & 179 & $\begin{array}{l}\text { Cross-sectional } \\
\text { survey }\end{array}$ & $\begin{array}{l}\text { Oxford } \\
\text { level of } \\
\text { evidence }\end{array}$ \\
\hline Gill et $a l^{4}$ & 2001 & $\begin{array}{l}\text { In } \\
\text { those with higher debt to exclude GP from their top } \\
\text { three preferences, however this was not statistically } \\
\text { significant. } \\
16 \% \text { stated level of debt as a very important and } \\
\text { strong influence on career choice. }\end{array}$
\end{tabular}

\begin{tabular}{|c|c|c|c|}
\hline Ling et $a l^{68}$ & 2018 & 3121 & $\begin{array}{l}\text { Cross-sectional } \\
\text { survey }\end{array}$ \\
\hline $\begin{array}{l}\text { Perry and } \\
\text { Wilkinson }^{26}\end{array}$ & 2010 & 372 & $\begin{array}{l}\text { Cross-sectional } \\
\text { survey }\end{array}$ \\
\hline
\end{tabular}

Medical and pharmacy students with higher debt were more likely to prefer rural practice. Medical students exhibited little influence of debt on career choice, and those with higher levels of debt were less concerned over career financial prospects. There was no correlation between debt level and interest in a primary care specialty.

$36 \%$ said debt influence specialty choice to at least 4 a moderate amount or more; $13 \%$ said less debt would change specialty decision, location of work or doing locum work. Those with greater debt were more likely to say having less debt would affect their career choice.

\begin{tabular}{lccl}
$\begin{array}{l}\text { McHardy et } \\
\text { al }\end{array}$ & 2008 & 115 & $\begin{array}{l}\text { Cross-sectional } \\
\text { survey }\end{array}$ \\
\hline $\begin{array}{l}\text { O'Grady and } \\
\text { Fitzjohn }\end{array}$ & 2001 & 407 & $\begin{array}{l}\text { Cross-sectional } \\
\text { survey }\end{array}$
\end{tabular}

$11 \%$ reported degree of debt would have a significant 4 influence on their career choice.

No significant influence, association between debt 4 and likelihood of practising overseas: $31.3 \%$ of students with debt $>60000$ planning to mainly or only practise overseas, compared with $20.3 \%$ of those with debts $<60000$.

\begin{tabular}{|c|c|c|}
\hline Singapore & & \\
\hline Fong, et al ${ }^{69}$ & 2018 & $\begin{array}{l}\text { Cross-sectional } \\
\text { survey }\end{array}$ \\
\hline
\end{tabular}

$40.5 \%$ of the 1241 students studied were to graduate 4 with debt. Those with debt (unadjusted OR 1.623, $95 \% \mathrm{Cl} 1.261$ to 2.090, $\mathrm{p}<0.001$; adjusted OR 1.393, $95 \% \mathrm{Cl} 1.048$ to $1.851, \mathrm{p}=0.022$ ) were more likely to have an economic factor very significantly influencing postgraduate training choices.

HEAL, health education assistance loans; N/A, not available.

\section{Effect on mental health}

The 14 studies identified that assessed the impact of debt on different aspects of medical student mental health included results from several countries: the USA, ${ }^{5} 16182256$ Canada, ${ }^{17192025} 27$ New Zealand, ${ }^{15} 26$ Scotland ${ }^{23}$ and Australia ${ }^{24}$ (table 1 ). These studies mainly focused on the effect of debt on stress levels, rather than on symptoms of anxiety or depression. Reported levels of financial stress were typically high and correlated with debt levels at a statistically significant level $(p<0.05)$ (table 1).

The publications with data collected from medical students in the USA found clear correlation between higher levels of debt and stress levels. In a study of 3032 postgraduate medical students, Rohlfing $e t a l^{22}$ found that each US\$50000 increase in medical student loan debt was associated with increased self-reported stress. This stress was mainly financial, that is, related to concerns over repaying or managing debt. Another study found increasing debt levels to be positively correlated with worry and negatively correlated with comfort when rated on a Likert scale. ${ }^{18}$

Canadian studies demonstrated that junior students were more likely to report significant stress associated with finances. For example, one study found first-year medical students were more likely to report that their financial situation was very or extremely stressful $(20.5 \%)$ compared with fourth-year students $(17.5 \%) .{ }^{25}$ Those earlier in their education were found to have higher anticipated debt levels, which accounted for an additional $11.5 \%$ variance in reported stress levels when added to current debt, over that predicted by current debt alone. ${ }^{20}$ It was also found that rural students had higher levels of financial stress compared with non-rural 


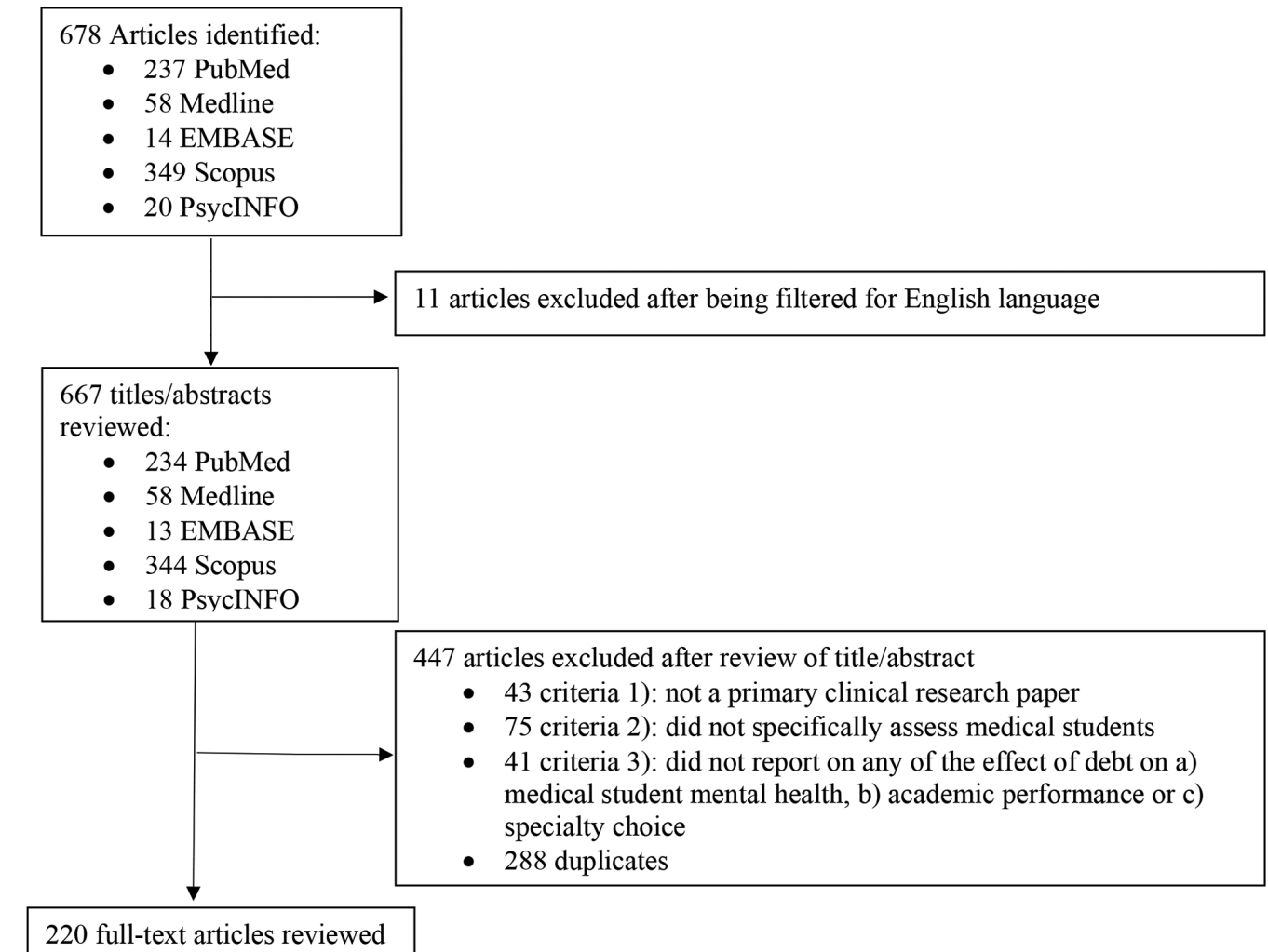

220 full-text articles reviewed

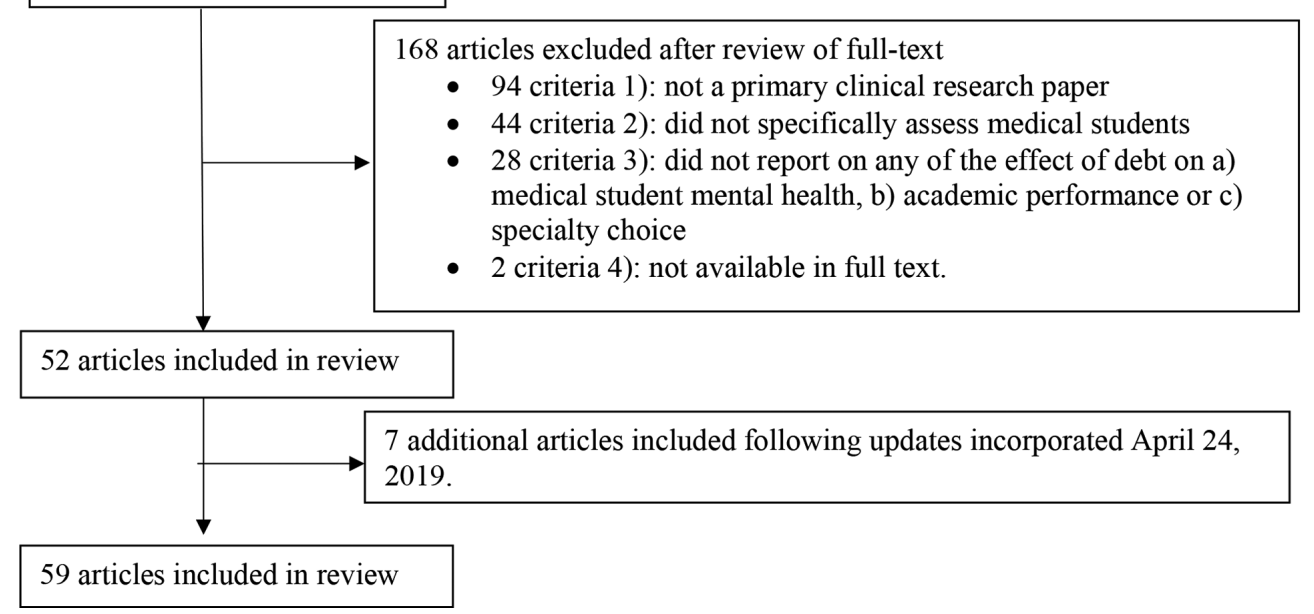

Figure 1 Flow chart detailing results of the search strategy and application of the eligibility criteria for a review of articles investigating the effects of medical student debt on mental health, academic performance or specialty choice.

students. ${ }^{17}$ These results were consistent with those seen in a large study by Merani $e t a l^{19}$ that examined the financial stress levels of 7795 medical students from across Canada, lower stress levels were experienced by students in Quebec (where medical school tuition had remained stable), compared with those outside Quebec (where medical student tuition had risen dramatically). ${ }^{19}$ A more recent 2018 study found that one of the predictors for burnout and psychological distress was feeling psychologically/emotionally unsupported at their university, which increased through the years of medical training. ${ }^{27}$

In contrast, a study of 170 New Zealand undergraduate students found that concern about debt was higher in more senior (sixth-year) students, and predictably, in those who had higher levels of debt. ${ }^{15}$ In this study, those who reported that they never worried about debt (14\%) had average debts of $\$ 2500$ (New Zealand Dollars (NZD)), whereas those reporting that they always worried about debt $(7 \%)$ had on average \$NZD86750 in debt. These results were supported by another New Zealand-based study, which showed a positive correlation between worry and indebtedness, with $32 \%$ of all students reporting worrying about debt 'often' or 'always'. ${ }^{26}$ Studies from Scotland and Australia reported similar findings. ${ }^{23} 24$

Another study used a prompted-essay type format to examine how medical students in the USA emotionally perceived debt in the context of career planning. ${ }^{56}$ Common themes highlighted by the authors suggested that the responding students felt their debt burdens reflected a lack of societal investment in medical 
education; that their sacrifices related to that debt were underappreciated by most outside of their profession and that these debt burdens and consequent sacrifices appeared to leave them feeling entitled to certain income and lifestyle expectations going forward. Also concerning, Jackson $e a^{16}{ }^{16}$ measured alcohol dependence in medical students using the Alcohol Use Disorders Identification Test screening tool, and found alcohol abuse/dependence was significantly more common in those with $>$ US $\$ 100000$ in educational debt $(p<0.01) .{ }^{16}$ Nonetheless, the majority of students considered their debt in a positive manner: $45 \%$ sought ways to avoid accumulating more, $22 \%$ managed debt proactively and only $2 \%$ deliberately avoided thinking about debt's consequences and ways to manage it. ${ }^{56}$

\section{Effect on academic performance}

The correlation between academic performance and debt was only investigated in four articles, ${ }^{4328} 29$ shown in table 2. Debt was negatively correlated with academic performance in three of these reports, ${ }^{423} 28$ while one study showed no correlation between debt and attrition rates (table 2). ${ }^{29}$

One group found suboptimal academic outcomes in those with debts over US $\$ 10000$, and a progressive decrease in the percentage of students graduating with optimal outcomes as debt rose; $90.1 \%$ of students with no debt achieved a passing score on their first attempt at a high stakes examination, while only $76.4 \%$ of those with debt $>$ US $\$ 50000$ passed on their first attempt. ${ }^{28}$ Ross et $a l^{23}$ found that although there was no significant relationship between total debt and class rank, the students who reported that financial worries affected their performance had lower class ranks and higher debt. ${ }^{23}$ Those who had a previous degree were also more likely to state that money affects their academic performance. ${ }^{23}$ Similarly, Gill et $a l^{15}$ analysed students' opinions of the effect of debt on their participation in the degree, and $21 \%$ of respondents stated that debt 'sometimes' impacted their ability to fully participate in their course of study. ${ }^{15}$ However, $46 \%$ stated debt never impacted them, and $31 \%$ said it rarely impacted them. ${ }^{15}$ Other studies have suggested that higher debt levels, ${ }^{70}$ or matriculation in MD-PhD programmes that are not 'fully funded' (ie, not supported by federal Medical Scientist Training Program (MSTP) funding), ${ }^{29}$ may increase likelihood of attrition from MD-PhD programmes.

\section{Effect on specialty choice}

The association between debt and specialty choice was assessed in a large number of studies, ${ }^{4511} 1217182122252630-69$ each of which are listed individually in table 3. There were more longitudinal studies in this area than there were studies that assessed the impact of debt on mental health or academic performance. The studies typically divided specialty choices into high paying specialties versus low paying areas (most commonly family practice/primary care). Higher paying specialties typically included surgery, dermatology, neurology, ophthalmology, radiology and other surgical and medical subspecialties. The results were varied. Overall, the majority (21) of the articles found that the presence of debt was associated with the choice of higher paying specialties. ${ }^{511} 1222$ 30-33373941 44-465155575964-67 Nine articles found that the presence of debt was associated with lower paying specialty choices. ${ }^{1722} 32384042445663$ A further 10 articles said there was no or minimal effect, ${ }^{343543474852-5462}$ and 13 articles found there was an association but did not further explore the nature of this relationship. ${ }^{41718252636495056606869}$ The majority of these studies were conducted in the USA (table 3).

\section{Studies conducted in the USA examining the effect of debt on specialty choice}

Twentyarticlesfrom the USA ${ }^{511122230-3337394144-465155575964-67}$ found that the presence of significant debt was associated with higher paying specialty choice. Eight articles $^{1722} 32384042445663$ found debt was associated with a greater degree with lower paying specialties like primary care/family practice and academic medicine, compared with other medical and surgical specialties. Nine US publications found that debt did not significantly influence specialty choice..$^{343543474852-5462}$ Four studies ${ }^{1849} 5660$ found that debt levels had an effect on specialty choice, but did not clarify in which direction.

One of the most authoritative studies in this area was a longitudinal study of 4916 US medical students, conducted by Grayson et $a l^{37}$ from 1992 to 2012. This study found that first-year and fourth-year medical students wanting to pursue high paying non-primary care careers anticipated a greater debt burden, placed higher importance on income and anticipated greater incomes, compared with their same-year peers seeking a career in primary care. Moreover, $31 \%$ of those reporting intending to pursue primary care at year 1 had decided to switch to a higher paying specialty by year 4 , with debt and income appearing to be driving factors. ${ }^{37}$ Another longitudinal study by Jeffe $e t a l^{11}$ found that from 1997 to 2006, the proportion of medical students with at least US $\$ 150000$ total debt at graduation rose from $6.7 \%$ to $35.9 \%$, in conjunction with a decline in the number of physicians pursuing generalised primary care. Similarly, Schwartz et al ${ }^{12}$ found greater debt in 2007 compared with 1990, and students in 2007 were more likely to report that debt repayments pushed them away from primary care careers. More recently, high debt levels (US\$150 000US\$249 999) of family medicine residents were associated with decreased odds of working in a government organisation, and very high debt levels (>US\$250 000) associated with decreased odds of academic practice or geriatric fellowships. ${ }^{64}$

Although less frequently examined, loan types were also found to play a role in specialty choice. For example, Bazzoli $^{32}$ examined both subsidised loans with lower interest rates that only accrue after graduation/residency, and health education assistance loans (HEAL) which 
had comparatively higher interest rates with accrual beginning from the date of taking the loan (ie, unsubsidised). Higher relative debt accrued from subsidised loan programmes seemed to predict primary care as a specialty choice, whereas higher (unsubsidised) HEAL debt was associated with higher paying specialties. ${ }^{32}$ These findings were consistent with more recent studies of osteopathic medical students. ${ }^{6566}$ Conversely, Nguyen and Bounds ${ }^{67}$ found that only $24 \%$ chose primary care despite having no student debt.

\section{Studies conducted outside the USA examining the effect of debt on specialty choice}

There were five Canadian studies ${ }^{1725365161}$ that looked at the effect of debt on specialty choice. Three articles found there was an affect but did not specify the influence, ${ }^{172536}$ one found higher debt was associated with a preference for family medicine ${ }^{61}$ and the remaining publication found debt to be associated with higher paying specialties. ${ }^{51}$ Two reports found that current debt load affected urban students' preference for specialty choice, but had no statistically significant influence for rural students. ${ }^{17} 36$ Vanasse $e t a{ }^{61}$ found that higher expected debt on completion of medical school was a strong predictor of desire to do family medicine. Morra $e t a{ }^{51}$ provided an interesting possible insight into this pattern. This study found that a large number of students agreed with the rationale of doing family medicine to start paying off their debt faster, as the residency is shorter. ${ }^{51}$

Several studies were identified that studied the influence of debt on specialty choice in New Zealand. ${ }^{4} 26068$ In these studies, debt was found to influence specialty choice, but generally it was not specified whether the directionality was towards higher paying specialties or primary care. McHardy et a $\tilde{D}^{0}$ found that $11 \%$ of students reported debt would have a significant influence on their career choice. Likewise, Gill et al found $16 \%$ of students stated level of debt as an important and strong influence on their career choice. They also noted that in sixth-year students there was a slight trend for those with higher debt to exclude general practice from their top three preferences but not to a statistically significant level. A more recent study from New Zealand found complex relationships that varied with one's medical profession, and preference for rural versus urban practice. ${ }^{68}$

One 2018 Singaporean study investigated the associations between economic factors and residency choices. It found $40.5 \%$ of the 1241 students studied were to graduate with debt, and these students were more likely to rank an economic factor as significantly influencing their postgraduate training. ${ }^{69}$

\section{DISCUSSION}

The majority of studies meeting the eligibility criteria and examined in this review support the notion that educational debt burden has a profound and often negative impact on medical students. Many studies reported debt as having adverse effects on student stress levels, and in some cases being associated with troubling patterns of alcohol use. ${ }^{16}$ Other reports strongly suggested that debt may also adversely affect academic performance.

Although few studies explored other aspects of students' mental health, one example that did assess other aspects of their mental health was an Australian study by Rogers $e t a l .^{24}$ This study identified personality traits that accounted for variances in levels of psychological stress: students with higher levels of extraversion, conscientiousness, professional expectations and lifestyle expectations, and lower levels of neuroticism, reported better well-being. In addition, future work could aim to prospectively investigate the interactions between resilience, debt and psychological distress in medical students. Results from such studies could underpin future targeted interventional strategies to maximise medical student mental health.

The influence of debt on specialty choice has been investigated much more extensively, although the majority of these studies have been conducted in the USA. These studies have produced conflicting results, and the generalisability of these findings to other countries with different socioeconomic structures may be limited. Another significant finding evident in multiple studies was differences between urban and rural students. Students from urban backgrounds were more likely to report debt as influencing their specialty choice and increasing the likelihood of them choosing higher paying specialties. Conversely, those from rural backgrounds were less likely to report an effect despite commonly having greater debt levels and/or coming from lower socioeconomic backgrounds. ${ }^{176}$ Together these findings illustrate the need to more clearly assess (and control for) whether one's socioeconomic background/financial liquidity in itself is a determinant of preferred practice area, with incurred debt being simply a consequence thereof, for example, do individuals of greater or lesser financial means gravitate towards higher or lower paying practice areas, and for what reasons-or are one's socioeconomic background and educational debt burden separate and independent predictors of specialty choice? Future studies in this area would help answer these key questions.

The vast majority of studies identified were cross-sectional in nature. Of the 52 articles included, there were only 6 prospective studies, ${ }^{29} 3741424959$ which primarily focused on the effects of debt on influencing specialty choice. The lack of longitudinal studies is important to consider, given the dynamic nature of debt and its capacity to compound. The majority of studies employed self-report questionnaires. Likert scale-type responses were commonly used. Few studies were identified that used alternative methodologies such as interviews or focus groups, although at least one study used a prompted-essay response design. ${ }^{56}$

Furthermore, no qualifying studies could be located that examined the effects of interventions targeting debt on medical student mental health, academic performance or 
specialty choice. Given debt's influence on these parameters has has been identified by the observational studies in this review, it may be reasonable to hypothesise that such interventions could influence these outcomes. Some possible debt-targeting interventions worth exploring for their effects on these outcomes, perhaps even in a prospective study, are loan forgiveness programmes. Along a similar theme, one report compared the impact of unsubsidised versus subsidised loans (a form of debt forgiveness) on specialty choice, and found those with greater unsubsidised loan burdens were more likely to pursue higher paying specialties. ${ }^{32}$ Further research yielded additional information on loan forgiveness. The US Public Service Loan Forgiveness programme, established in 2007, advertises complete (remaining) loan forgiveness for public-sector/non-profit employees after they have made 120 qualifying monthly payments. One study found more future primary care physicians intended to use this programme compared with programmes expressly designed to promote primary care. ${ }^{71}$ A survey on physician recruiting incentives reported that for $31 \%$ of respondents, whether or not a potential employer (eg, a hospital) offered educational loan forgiveness as a job incentive would have a great effect on selecting an offer. ${ }^{72}$ Findings from a very recent study of osteopathic medical graduates 'consistently showed that graduates with a loan forgiveness/repayment programme were more likely to choose primary care over graduates without such a programme'. ${ }^{65}$ Another similar recent study reported that osteopathic 'graduates with the most debt intended to practice in underserved areas at a higher percentage than those with the least amount of debt, and they also planned on using loan-repayment programmes at a higher rate' ${ }^{66}$ More studies are needed in these areas, to determine whether loan forgiveness or similar programmes can obviate some the negative impacts that debt burden has on medical student mental health, academic performance and specialty choice.

Interestingly, while many studies supported the notion that significant medical school debt may drive some graduates away from primary care or other lower paying practice areas, particularly in the absence of loan repayment programmes, the converse may not necessarily be true, that is, at least one recent study suggests that the absence of medical student debt alone does not appear to drive more graduates into primary care. ${ }^{67}$

The majority of articles assessed whole-year level cohorts and were anonymous, which helped to minimise any selective reporting bias. However, many studies had small sample sizes, the smallest being $27,{ }^{33}$ while some sample sizes were not specified. ${ }^{41}$ This raises the issue of possible non-response bias, which could have influenced results in studies with smaller sample sizes. There was also concern of differing stress levels depending on the time of the year the survey was administered. Ross $e t a l^{23}$ acknowledged this, with their survey being released just before the examination period, which may have contributed to general stress levels as well as low response rate.
Because our initial full search and meta-analysis was performed in April 2017, which is a potential limitation of this study for publication in 2019, we incorporated key search updates on 24 April 2019. This more recent search revealed similar findings to those already concluded, in particular the majority of articles being related to specialty choice. Examples of the most recent studies $^{64-69}$ are included throughout the 'Results' and 'Discussion' sections.

We also recognise the exclusion of non-English language publications as a potential limitation of this review. Additionally, there is the possibility of selective outcome reporting or publication bias that may have influenced the conclusions formed.

Additional prospective studies investigating the effects of debt on all three areas examined in this review are likely to be beneficial, especially regarding the influence of debt on medical student mental health. Furthermore, the international generalisability of studies conducted in other countries may be limited, due to a range of often significant cultural, socioeconomic, sociopolitical and structural differences regarding the costs and financial responsibilities for medical education. Many countries around the world, for example, have far greater opportunities for tuition-free medical education than others, thus making medical education debt a non-issue for some students. Accordingly, studies examining these issues may be warranted in countries in which it has not yet been examined. Future interventional studies may be useful, for example, in regard to addressing shortages of primary care physicians.

\section{CONCLUSIONS}

Medical student debt is negatively associated with mental well-being, academic outcomes and may drive physicians to practice in higher paying specialty areas rather than primary care. Further prospective studies are warranted, and student debt may be a suitable target for interventional studies aiming to improve or influence these outcomes in future.

Contributors Conception of the work: JL, M-LW, SB, MSP. Design of the work: MSP, SB, ATA, SWP. Acquisition, analysis or interpretation of data: MSP, SB, ATA, SWP, MW, M-LW, JL. Drafted the manuscript: MSP, SB, ATA. Revised the manuscript for intellectual content: SWP, MW, M-LW, JL.

Funding This work was supported by institutional funds from the University of Adelaide, and from the State University of New York (SUNY) Upstate Medical University. This paper is subject to the SUNY Open Access Policy.

Competing interests None declared.

Patient consent for publication Not required.

Provenance and peer review Not commissioned; externally peer reviewed.

Data sharing statement All data relevant to the study are included in the article or uploaded as supplementary information.

Open access This is an open access article distributed in accordance with the Creative Commons Attribution Non Commercial (CC BY-NC 4.0) license, which permits others to distribute, remix, adapt, build upon this work non-commercially, and license their derivative works on different terms, provided the original work is 
properly cited, appropriate credit is given, any changes made indicated, and the use is non-commercial. See: http://creativecommons.org/licenses/by-nc/4.0/.

\section{REFERENCES}

1. Association of American Medical Colleges. Medical student education: Debt, costs, and loan repayment fact card: Association of American Medical Colleges.

2. Youngclaus J, Fresne JA. Physician education debt and the cost to attend medical school: 2012 update: Association of American Medical Colleges, 2013.

3. Steinbrook R. Medical student debt--is there a limit? N Engl J Med 2008;359:2629-32.

4. Gill D, Palmer C, Mulder R, et al. Medical student career intentions at the Christchurch School of Medicine. The New Zealand Wellbeing, Intentions, Debt and Experiences (WIDE) survey of medical students pilot study. Results part II. N Z Med J 2001;114:465-76.

5. Hafferty FW, Boulger JG. A look by medical students at medical practice in the future. J Med Educ 1986;61:359-67.

6. Jorm AF. Why hasn't the mental health of Australians improved? The need for a national prevention strategy. Aust N Z J Psychiatry 2014;48:795-801.

7. Rotenstein LS, Ramos MA, Torre M, et al. Prevalence of Depression, Depressive Symptoms, and Suicidal Ideation Among Medical Students: A Systematic Review and Meta-Analysis. JAMA 2016;316:2214-36.

8. Study Assist - Loan repayment. https://www.studyassist.gov.au/ paying-back-my-loan/loan-repayment (Accessed 27 Aug 2018)

9. Norwood A. The 3 Main Categories Of Financial Aid. https://www. saltmoney.org/content/media/Article/the-three-main-categories-offinancial-aid/_/R-101-18405?WT.mc_id=ME-ASAORG\&unblocked= true (Accessed 27 Aug 2018).

10. Student Financial Assistance. https://www.canada.ca/en/services/ jobs/education/student-financial-aid.html (Accessed 27 Aug 2018).

11. Colquitt WL, Zeh MC, Killian CD, et al. Effect of debt on U.S. medical school graduates' preferences for family medicine, general internal medicine, and general pediatrics. Acad Med 1996;71:399-411.

12. Schwartz MD, Durning S, Linzer M, et al. Changes in medical students' views of internal medicine careers from 1990 to 2007. Arch Intern Med 2011;171:744-9.

13. JAMA Psychiatry JN. Instructions for Authors. 2019 https:// jamanetwork.com/journals/jamapsychiatry/pages/instructions-forauthors.

14. CEBM. OCEBM Levels of Evidence: CEBM, 2019.

15. Gill D, Palmer C, Mulder R, et al. Medical student debt at the Christchurch School of Medicine. The New Zealand Wellbeing, Intentions, Debt and Experiences (WIDE) survey of medical students pilot study. Results part I. N Z Med J 2001;114:461-4.

16. Jackson ER, Shanafelt TD, Hasan O, et al. Burnout and Alcoho Abuse/Dependence Among U.S. Medical Students. Acad Med 2016;91:1251-6.

17. Kwong JC, Dhalla IA, Streiner DL, et al. A comparison of Canadian medical students from rural and non-rural backgrounds. Can J Rural Med 2005;10:36-42.

18. Marci CD, Roberts TG. The increasing debt of medical students: how much is too much? JAMA 1998;280:1879-80.

19. Merani S, Abdulla S, Kwong JC, et al. Increasing tuition fees in a country with two different models of medical education. Med Educ 2010;44:577-86.

20. Morra DJ, Regehr G, Ginsburg S. Anticipated debt and financial stress in medical students. Med Teach 2008;30:313-5.

21. Phillips JP, Weismantel DP, Gold KJ, et al. Medical student debt and primary care specialty intentions. Fam Med 2010;42:616-22.

22. Rohlfing J, Navarro R, Maniya OZ, et al. Medical student debt and major life choices other than specialty. Med Educ Online 2014;19:25603.

23. Ross S, Cleland J, Macleod MJ. Stress, debt and undergraduate medical student performance. Med Educ 2006;40:584-9.

24. Rogers ME, Creed PA, Searle J. Person and environmental factors associated with well-being in medical students. Pers Individ Dif 2012;52:472-7.

25. Kwong JC, Dhalla IA, Streiner DL, et al. Effects of rising tuition fees on medical school class composition and financial outlook. CMAJ 2002;166:1023-8.

26. Perry WR, Wilkinson TJ. Taking the pulse: medical student workforce intentions and the impact of debt. N Z Med J 2010;123:15-23.

27. McLuckie A, Matheson KM, Landers AL, et al. The Relationship Between Psychological Distress and Perception of Emotional Support in Medical Students and Residents and Implications for Educational Institutions. Acad Psychiatry 2018;42:41-7.
28. Andriole DA, Jeffe DB. Prematriculation variables associated with suboptimal outcomes for the 1994-1999 cohort of US medical school matriculants. JAMA 2010;304:1212-9.

29. Jeffe DB, Andriole DA, Wathington HD, et al. Educational outcomes for students enrolled in MD-PhD programs at medical school matriculation, 1995-2000: a national cohort study. Acad Med 2014;89:84-93.

30. Andriole DA, Whelan AJ, Jeffe DB. Characteristics and career intentions of the emerging MD/PhD workforce. JAMA 2008;300:1165-73.

31. Azizzadeh A, McCollum CH, Miller CC, et al. Factors influencing career choice among medical students interested in surgery. Curr Surg 2003;60:210-3.

32. Bazzoli GJ. Does educational indebtedness affect physician specialty choice? J Health Econ 1985;4:1-19.

33. Curran MA, Black M, Depp CA, et al. Perceived barriers and facilitators for an academic career in geriatrics: medical students' perspectives. Acad Psychiatry 2015;39:253-8.

34. Diamond JJ, Ruth DH, Markham FW, et al. Specialty Selections of Jefferson Medical College Students. Eval Health Prof 1994;17:322-8.

35. Gil JA, Waryasz GR, Liu D, et al. Influence of Medical Student Debt on the Decision to Pursue Careers in Primary Care. $R$ I Med J 2016;99:19-21.

36. Gill H, McLeod S, Duerksen K, et al. Factors influencing medical students' choice of family medicine: effects of rural versus urban background. Can Fam Physician 2012;58:e649-e657.

37. Grayson MS, Newton DA, Thompson LF. Payback time: the associations of debt and income with medical student career choice. Med Educ 2012;46:983-91.

38. Greenberg RB, Ziegler $\mathrm{CH}$, Borges NJ, et al. Medical student interest in academic medical careers: a multi-institutional study. Perspect Med Educ 2013;2:298-316.

39. Hauer KE, Durning SJ, Kernan WN, et al. Factors associated with medical students' career choices regarding internal medicine. JAMA 2008;300:1154-64.

40. Henderson MC, Hunt DK, Williams JW. General internists influence students to choose primary care careers: the power of role modeling. Am J Med 1996;101:648-53.

41. Jeffe DB, Whelan AJ, Andriole DA. Primary care specialty choices of United States medical graduates, 1997-2006. Acad Med 2010;85:947-58.

42. Jeffe DB, Andriole DA, Hageman HL, et al. Reaping what we sow: the emerging academic medicine workforce. J Natl Med Assoc 2008;100:1026-35.

43. Kahn MJ, Markert RJ, Lopez FA, et al. Is medical student choice of a primary care residency influenced by debt? MedGenMed 2006;8:18.

44. Kassebaum DG, Szenas PL. Relationship between indebtedness and the specialty choices of graduating medical students: 1993 update. Acad Med 1993;68:934-7.

45. Kassebaum DG, Szenas PL. Factors influencing the specialty choices of 1993 medical school graduates. Acad Med 1994;69:163-70.

46. Kassebaum DG, Szenas PL, Caldwell K. Educational debt, specialty choices, and practice intentions of underrepresented-minority medical school graduates. Acad Med 1993;68:506-11.

47. Kassebaum DG, Szenas PL, Schuchert MK. Determinants of the generalist career intentions of 1995 graduating medical students. Acad Med 1996;71:198-209.

48. Kassler WJ, Wartman SA, Silliman RA. Why medical students choose primary care careers. Acad Med 1991;66:41-3.

49. Mader EM, Roseamelia C, Morley CP. The temporal decline of idealism in two cohorts of medical students at one institution. BMC Med Educ 2014;14:58.

50. McHardy KM, Janssen A, Poole PJ. Female medical students may accrue less student loan debt than their male colleagues in New Zealand. N Z Med J 2008;121:37-44.

51. Morra DJ, Regehr G, Ginsburg S. Medical students, money, and career selection: students' perception of financial factors and remuneration in family medicine. Fam Med 2009;41:105-10.

52. Mutha S, Takayama JI, O'Neil EH. Insights into medical students career choices based on third- and fourth-year students' focusgroup discussions. Acad Med 1997;72:635-40.

53. O'Grady G, Fitzjohn J. Debt on graduation, expected place of practice, and career aspirations of Auckland Medical School students. N Z Med J 2001;114:468-70.

54. Paiva RE, Vu NV, Verhulst SJ. The effect of clinical experiences in medical school on specialty choice decisions. J Med Educ 1982;57:666-74.

55. Park R. Graduating medical students' debt and specialty choices. Acad Med 1990;65:485-6. 
56. Phillips JP, Wilbanks DM, Salinas DF, et al. Educational Debt in the Context of Career Planning: A Qualitative Exploration of Medical Student Perceptions. Teach Learn Med 2016;28:243-51.

57. Rosenblatt RA, Andrilla CH. The impact of U.S. medical students debt on their choice of primary care careers: an analysis of data from the 2002 medical school graduation questionnaire. Acad Med 2005;80:815-9.

58. Rosenthal MP, Diamond JJ, Rabinowitz HK, et al. Influence of income, hours worked, and loan repayment on medical students decision to pursue a primary care career. JAMA 1994;271:914-7.

59. Rosenthal MP, Marquette PA, Diamond JJ. Trends along the debtincome axis. Acad Med 1996;71:675-7.

60. Teitelbaum HS, Ehrlich N, Travis L. Factors affecting specialty choice among osteopathic medical students. Acad Med 2009;84:718-23.

61. Vanasse A, Orzanco MG, Courteau J, et al. Attractiveness of family medicine for medical students: influence of research and debt. Can Fam Physician 2011;57:e216-27.

62. Wilbanks L, Spollen J, Messias E. Factors Influencing Medical School Graduates Toward a Career in Psychiatry: Analysis from the 2011-2013 Association of American Medical Colleges Graduation Questionnaire. Acad Psychiatry 2016;40:255-60.

63. McLaughlin MA, Daugherty SR, Rose WH, et al. The impact of medical school debt on postgraduate career and lifestyle. Acad Med 1991;66:S43-5.

64. Phillips JP, Peterson LE, Fang B, et al. Debt and the Emerging Physician Workforce: The Relationship Between Educational Debt and Family Medicine Residents' Practice and Fellowship Intentions. Acad Med 2019;94:267-73.

65. Scheckel CJ, Richards J, Newman JR, et al. Role of debt and loan forgiveness/repayment programs in osteopathic medical graduates' plans to enter primary care. J Am Osteopath Assoc 2019;119:227-35.

66. Richards JR, Scheckel CJ, Kunz M, et al. Practice area intentions of graduates of colleges of osteopathic medicine: what role does debt play? J Am Osteopath Assoc 2018;118:384-8.

67. Nguyen BM, Bounds G. Factors affecting specialty choice among doctors who received tuition scholarships. Fam Med 2019;51:276-81.

68. Ling S, Jacobs R, Ponton R, et al. Influence of student debt on health career location and specialty. J Prim Health Care 2018;10:54-61.

69. Fong JMN, Tan YTW, Sayampanathan AA, et al. Impact of financial background and student debt on postgraduate residency choices of medical students in Singapore. Singapore Med J 2018;59:647-51.

70. Watt CD, Greeley SA, Shea JA, et al. Educational views and attitudes, and career goals of MD-PhD students at the University of Pennsylvania School of Medicine. Acad Med 2005;80:193-8.

71. Friedman AB, Grischkan JA, Dorsey ER, et al. Forgiven but not relieved: US Physician workforce consequences of changes to public service loan forgiveness. J Gen Intern Med 2016;31:1237-41.

72. Merritt-Hawkins. Survey of Final-Year Medical Residents. 2017 https://www.merritthawkins.com/uploadedfiles/mha_2017_resident survey.pdf2017. 